\title{
Clinical Reasoning: A 16-year-old girl with ataxia, oscillopsia, and behavioral changes
}

Andrew Silverman, ScB, Chindhuri Selvadurai, MD, John Picard, MD, Lauren Gluck, MD, Adeniyi Fisayo, MD, PharmD, Naila Makhani, MD, MPH, and Viviana Benitez, MD

Neurology ${ }^{\circledR}$ 2020;94:713-717. doi:10.1212/WNL.0000000000009297

\section{Section 1}

A 16-year-old girl with no relevant medical history presented with 1 week of vertigo, tremulousness, and gait instability. She described the room as "moving and unsteady." She reported anxiety and had a panic attack in the emergency department. In the months prior to presentation, she displayed atypical irritability and aggressiveness toward her siblings. One week before the onset of vertigo, she completed a 5-day course of azithromycin for presumed sinusitis. She had not traveled in the prior year. The patient denied drug or alcohol use, sexual activity, sick contacts, or any recent tick or mosquito bites.

On examination, the patient had slow, soft, and deliberate speech but was alert and oriented to person, place, time, and situation. She had intact naming, comprehension, and repetition. She was able to register and recall $3 / 3$ words. Her ocular ductions were full. However, there were constant, rapid eye movements in both horizontal and vertical directions, mostly observed in primary gaze and with fixation. The movements were conjugate and of moderate amplitude and high frequency (video 1, part 1). There was no slow phase. Dix-Hallpike and head impulse testing were negative. There was no intention tremor, dysdiadochokinesia, or dysmetria on initial examination, although the patient later developed bilateral dysmetria on day 3 of her hospitalization. She had prominent truncal ataxia, which limited gait assessment. The remainder of her examination was unremarkable.

\section{Questions for consideration:}

1. How would you localize this patient's presentation?

2. How would you characterize her eye movements?
Correspondence

A. Silverman

andrew.silverman@yale.edu
MORE ONLINE

Video

GO TO SECTION 2 
Table 1 Different features of saccadic intrusions, stratified by the presence or absence of an intersaccadic interval

\begin{tabular}{|c|c|c|c|c|}
\hline \multicolumn{3}{|c|}{ Saccadic intrusions with an intersaccadic interval } & \multicolumn{2}{|c|}{$\begin{array}{l}\text { Saccadic intrusions without } \\
\text { an intersaccadic interval }\end{array}$} \\
\hline Square-wave jerks & Macrosquare-wave jerks & Macrosaccadic oscillations & $\begin{array}{l}\text { Ocular } \\
\text { flutter }\end{array}$ & Opsoclonus \\
\hline $\begin{array}{l}\text { Small amplitude conjugate couplets } \\
\text { of horizontal saccades with } \\
\text { intersaccadic latency of } 150-200 \mathrm{~ms}\end{array}$ & $\begin{array}{l}\text { Also known as square-wave pulse; } \\
\text { larger amplitude and shorter } \\
\text { intersaccadic latency of } 80 \mathrm{~ms}\end{array}$ & $\begin{array}{l}\text { Horizontal saccades with crescendo- } \\
\text { decrescendo amplitudes with } \\
\text { intersaccadic latency of } 150-200 \mathrm{~ms}\end{array}$ & $\begin{array}{l}\text { Rapid } \\
\text { oscillations } \\
\text { limited to one } \\
\text { plane }\end{array}$ & $\begin{array}{l}\text { Rapid } \\
\text { multidirectional } \\
\text { saccadic } \\
\text { oscillations }\end{array}$ \\
\hline
\end{tabular}

Reference 1 provides a more in-depth review of these saccadic intrusions.

\section{Section 2}

The patient's presentation localizes to several locations, including the medulla (vertigo) and pons/cerebellum (oscillopsia, ataxia, scanning speech, as well as possible behavioral changes). Her rapid and repetitive eye movements can be categorized as ocular flutter or opsoclonus. The lack of a slow phase rules out nystagmus, and the rapidity renders pendular nystagmus unlikely. The movements are instead saccadic intrusions, which must be differentiated from saccades with normal intersaccadic intervals, such as square wave jerks (table 1). In contrast, saccadic oscillations like ocular flutter and opsoclonus comprise rapid conjugate oscillations, mostly in primary gaze, and cause oscillopsia (the illusion of an unstable world). Ocular flutter is limited to one plane, whereas opsoclonic oscillations can be multidirectional with varying amplitude and frequency. ${ }^{1}$

\section{Question for consideration:}

1. Based on your clinical impression and differential diagnosis, what would you do next? 

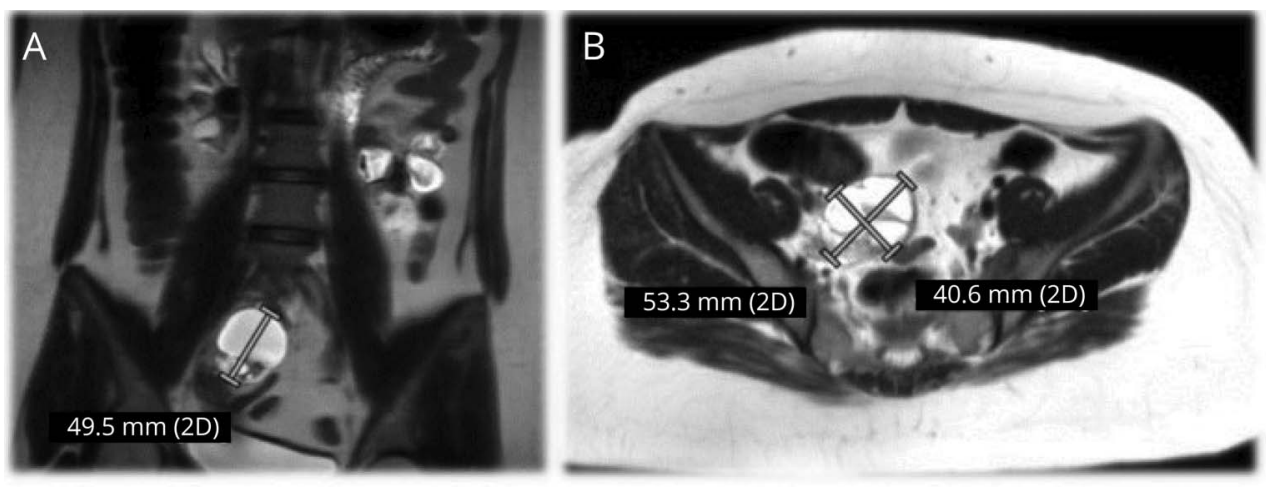

(A) Coronal and (B) axial MRI of a right-sided ovarian mass with solid and cystic components. Radiologic findings were compatible with ovarian teratoma.

\section{Section 3}

Given our patient's ataxia and multidirectional saccadic oscillations with abnormal intersaccadic intervals, the clinical impression was believed to reflect opsoclonus-ataxia syndrome. In considering our patient's recent upper respiratory symptoms and age, the differential diagnosis for opsoclonusataxia syndrome was broad and included parainfectious, primary autoimmune, or paraneoplastic encephalitis syndromes, as well as demyelinating and metabolic disorders, such as celiac, hypoglycemia, uremia, and cobalamin, thiamine, or vitamin E deficiency. Accordingly, the workup must include serum and CSF studies and brain imaging to look for infectious and inflammatory markers. With concern for paraneoplastic processes, one should also acquire appropriate imaging of the chest, abdomen, and pelvis to rule out mass or malignancy. Opsoclonus-ataxia (often associated with myoclonus) is frequently seen in the context of pediatric neuroblastoma, but this syndrome typically affects younger children. ${ }^{1-3}$ Regarding autoimmune encephalitis, antibodies from both serum and CSF should be tested.

Our patient's serum laboratory studies were notable for leukocytosis $(14,000$ cells $/ \mu \mathrm{L})$ as well as a mildly elevated alanine aminotransferase ( $35 \mathrm{U} / \mathrm{L})$, aspartate aminotransferase (42 U/ $\mathrm{L})$, and erythrocyte sedimentation rate $(41 \mathrm{~mm} / \mathrm{h})$. The remainder of her bloodwork, including a complete metabolic panel, thyroid-stimulating hormone, cobalamin, folate, vitamins
A and E, antinuclear antibody, C-reactive protein, ceruloplas$\mathrm{min}$, and angiotensin-converting enzyme, were within normal limits. Her hepatitis panel was negative. CSF examination was remarkable for 303 nucleated cells/ $\mu \mathrm{L}$ (93\% lymphocytes), elevated protein $(74.3 \mathrm{mg} / \mathrm{dL}), 10$ erythrocytes, a normal CSF/ plasma glucose ratio of 54/98 (0.56), as well as a normal opening pressure of $22 \mathrm{~mm} \mathrm{Hg}$. Immunoglobulin $\mathrm{G}$ index was normal $(0.68$, normal $<0.8)$, but there were more than 2 CSFunique oligoclonal bands. CSF Gram stain was negative, and there were no organisms grown in culture. CSF PCR did not amplify herpes simplex virus (HSV) or varicella-zoster virus DNA. Cytology and flow cytometry were negative for malignancy. The CSF and serum paraneoplastic antibody panels were also negative.

MRI of the brain with and without contrast did not reveal evidence of inflammation or demyelination. The cerebellum and brainstem showed no abnormalities. MRI of the chest, abdomen, and pelvis revealed a right-sided ovarian mass containing solid and cystic components (figure). The solid component displayed mild enhancement, in keeping with a teratoma. The left adnexa and ovary were unremarkable.

\section{Questions for consideration:}

1. What is the most likely diagnosis?

2. How would you interpret the patient's CSF profile in the context of an ovarian teratoma?

\section{GO TO SECTION 4}


Table 2 Five case reports of opsoclonus-ataxia syndrome associated with ovarian teratoma

\begin{tabular}{|c|c|c|c|c|c|}
\hline Case report & Age, y/sex & $\begin{array}{l}\text { Presenting symptoms prior to } \\
\text { developing opsoclonus }\end{array}$ & MRI brain & Antibody & Immunotherapy \\
\hline Fitzpatrick et al. ${ }^{4}$ & $15 / F$ & Nausea, vomiting, unsteady on feet & Normal & Negative & IVMP, IVIg \\
\hline Lou et al. ${ }^{5}$ & $26 / F$ & Abdominal pain & Normal & Negative & IVMP, IVIg, PLEX, rituximab \\
\hline Kawachi et al. ${ }^{6}$ & $24 / F$ & Abdominal pain, vertigo, unstable gait & Normal & Negative & IVMP, IVIg \\
\hline Kanno et al. ${ }^{7}$ & $16 / F$ & Vertigo, unstable gait & Normal & Negative & IVMP, IVIg \\
\hline Urriola et al. ${ }^{8}$ & $26 / \mathrm{F}$ & Imbalance, nausea, vomiting & Normal & NMDA+ & IVMP, PLEX, rituximab \\
\hline
\end{tabular}

Abbreviations: IVIg = IV immunoglobulin; IVMP = IV methylprednisolone; PLEX = plasma exchange.

All patients underwent surgery to remove the teratoma via salpingo-oophorectomy.

\section{Section 4}

In light of the ovarian teratoma, the most likely diagnosis is a paraneoplastic process producing opsoclonus-ataxia syndrome. Management calls for an immunosuppressive regimen, but the patient's CSF profile was concerning for a potential infectious etiology. Indeed, the lymphocytic pleocytosis was believed to be higher than might be anticipated for a paraneoplastic syndrome, and so an infectious disease consultation was requested prior to starting steroids.

Additional studies recommended by the infectious disease team included CSF PCR for Epstein-Barr virus and cytomegalovirus, West Nile virus antibodies from serum and CSF, an arbovirus antibody panel from CSF, enterovirus PCR from serum, stool, and the nasopharynx, Mycoplasma pneumoniae PCR from the nasopharynx, as well as anaplasma and Ehrlichia PCR from serum, and they were ultimately negative. While the CSF pleocytosis called for a wide diagnostic net, the teratoma represented a readily identifiable etiology of the patient's neurologic syndrome. Nevertheless, the chief concern prior to steroid initiation was HSV encephalitis, as this viral etiology would have guided management towards an antiviral, rather than immunosuppressive, regimen. The patient received a $500 \mathrm{mg}$ dose of IV acyclovir in the interim, but as soon as the CSF HSV PCR returned negative, both infectious disease and neurology teams were comfortable administering steroids, as the main concern pertained to paraneoplastic encephalitis with opsoclonus-ataxia and teratoma.

The gynecology-oncology service was called, and the patient underwent a laparoscopic right salpingo-oophorectomy. Concurrently, the patient began a 2-day course of IV immunoglobulin (IVIg) $1 \mathrm{~g} / \mathrm{kg} / \mathrm{d}$ as well as a 5 -day course of IV methylprednisolone $1 \mathrm{~g} / \mathrm{d}$. The patient's opsoclonus improved after the first day of IVIg and steroids, as did her subjective sense of vertigo (video, part 2). After the complete 2 days of IVIg and 5 days of steroids, her ocular flutter and dysmetria continued to improve, and she no longer felt dizzy (video, part 3).

\section{Discussion}

\section{A brief history and proposed mechanism of opsoclonus}

Under the mentorship of Dr. Paul Sandifer, Dr. Marcel Kinsbourne first described opsoclonus in $1962 .{ }^{3}$ Since then, a mechanism for these saccadic oscillations has been proposed. In particular, Purkinje cell lesions may disinhibit the deep cerebellar fastigial nucleus, leading to inhibition of omnipause cells. These pause cells normally provide tonic inhibition for excitatory burst neurons in the paramedian pontine reticular formation (PPRF), which controls horizontal saccades. Loss of inhibitory tone from pause cells can lead to uncontrolled burst firing patterns in the PPRF and, therefore, "dancing eyes" via abducens and oculomotor nuclei. ${ }^{1}$

\section{Ovarian teratoma-associated opsoclonus}

In reviewing the literature on opsoclonus-ataxia syndrome associated with ovarian teratoma, we identified 5 total published individual case reports (table 2). In addition, in a large retrospective review of 249 patients with teratoma-related encephalitis, only 10 (4\%) developed opsoclonus. ${ }^{9}$ All 10 patients were NMDA antibody-negative. After teratoma resection and varying immunosuppressive regimens, 8 of these patients completely recovered, and 2 were left with mild ataxia after 15 months. The authors noted that this teratomaassociated encephalitis, seen primarily in young female patients, appeared to be responsive to immunotherapy. Furthermore, they noted frequent CSF pleocytosis ( $\mathrm{n}=7$ of 10 , median $=37$ white blood cells $/ \mu \mathrm{L}$, range $=10-182)$ and elevated CSF protein $(\mathrm{n}=5$, median $=64 \mathrm{mg} / \mathrm{dL}$, range $=$ 49-100). Together, the constellation of an immunotherapyresponsive brainstem-cerebellar syndrome in the setting of a teratoma points strongly to an immune-mediated paraneoplastic process, although specific antibody-antigen characterization has yet to be elucidated. ${ }^{8,9}$ This literature review illustrates that our patient's presentation fits within the framework of published cases of opsoclonus associated with ovarian teratoma, and that the prognosis with immunosuppressive therapy is favorable. 
From bench to bedside: neuroimmunology and opsoclonus-ataxia syndrome

Flow cytometry analysis of our patient's CSF provides an interesting perspective on future management. In addition to the presence of oligoclonal bands, her CSF was notable for mild expansion of CD19+ (9.3\%) and CD19+ CD20+ B cells (7.8\%). Thus, she may benefit from B-cell depletion therapy (i.e., rituximab). Following the discovery that CSF B-cell elevation correlates with symptom severity in opsoclonusmyoclonus syndrome, the use of rituximab has been shown to be effective in rapid induction in such patients alongside marked depletion of CSF B-cell counts. ${ }^{2}$ Numerous findings point to an increasingly strong hypothesis that B cells play a key role in the syndrome's pathogenesis (e.g., oligoclonal banding, B-cell expansion, rituximab's ability to disrupt B-cell trafficking into the CSF, and the presence of B-cell activating factor and chemoattractant CXCL13 in CSF). ${ }^{1,10}$

We describe a patient with a rarely reported brainstemcerebellar encephalitis associated with ovarian teratoma. Proper placement of her abnormal eye movements in the ocular flutter-opsoclonus spectrum was critical in making the diagnosis. Indeed, any female teenager or young adult who presents with subacute ataxia and ocular flutter or opsoclonus should undergo imaging of the chest, abdomen, and pelvis to rule out masses like neuroblastoma, ganglioneuroblastoma, breast cancer, small-cell lung cancer, and gynecologic tumors. ${ }^{9}$ To our knowledge, this case represents the 16th published report of teratoma-associated opsoclonus. Our patient's symptoms quickly improved with first-line immunosuppressive intervention (IVIg and methylprednisolone). Because of residual eye movement abnormalities (though the patient reported $>50 \%$ improvement following IVIg and steroids), 1,000 $\mathrm{mg}$ of IV rituximab was administered in the outpatient setting, with a plan to repeat dosing in 6 months if symptoms persist.

\section{Study funding}

This report received no targeted funding.

\section{Disclosure}

The authors report no relevant disclosures. Go to Neurology. org/ $\mathrm{N}$ for full disclosures.

\section{Appendix Authors}

\begin{tabular}{|c|c|c|}
\hline Name & Location & Contribution \\
\hline $\begin{array}{l}\text { Andrew } \\
\text { Silverman, } \\
\text { ScB }\end{array}$ & $\begin{array}{l}\text { Yale University } \\
\text { School of } \\
\text { Medicine }\end{array}$ & $\begin{array}{l}\text { Case concept and design, primary } \\
\text { authorship }\end{array}$ \\
\hline $\begin{array}{l}\text { Chindhuri } \\
\text { Selvadurai, } \\
\text { MD }\end{array}$ & $\begin{array}{l}\text { Yale University } \\
\text { School of } \\
\text { Medicine }\end{array}$ & Provided patient care and revisions \\
\hline $\begin{array}{l}\text { John Picard, } \\
\text { MD }\end{array}$ & $\begin{array}{l}\text { Yale University } \\
\text { School of } \\
\text { Medicine }\end{array}$ & Provided patient care and revisions \\
\hline $\begin{array}{l}\text { Lauren Gluck, } \\
\text { MD }\end{array}$ & $\begin{array}{l}\text { Yale University } \\
\text { School of } \\
\text { Medicine }\end{array}$ & $\begin{array}{l}\text { Provided patient care and revisions } \\
\text { for intellectual content }\end{array}$ \\
\hline $\begin{array}{l}\text { Adeniyi } \\
\text { Fisayo, MD, } \\
\text { PharmD }\end{array}$ & $\begin{array}{l}\text { Yale University } \\
\text { School of } \\
\text { Medicine }\end{array}$ & $\begin{array}{l}\text { Provided neuro-ophthalmologic } \\
\text { expertise }\end{array}$ \\
\hline $\begin{array}{l}\text { Naila } \\
\text { Makhani, MD, } \\
\text { MPH }\end{array}$ & $\begin{array}{l}\text { Yale University } \\
\text { School of } \\
\text { Medicine }\end{array}$ & $\begin{array}{l}\text { Provided neuroimmunologic } \\
\text { expertise }\end{array}$ \\
\hline $\begin{array}{l}\text { Viviana } \\
\text { Benitez, MD }\end{array}$ & $\begin{array}{l}\text { Yale University } \\
\text { School of } \\
\text { Medicine }\end{array}$ & $\begin{array}{l}\text { Case concept, critical revision of } \\
\text { manuscript for intellectual content, } \\
\text { and provided neuro-oncologic } \\
\text { expertise }\end{array}$ \\
\hline
\end{tabular}

\section{References}

1. Lemos J, Eggenberger E. Saccadic intrusions: review and update. Curr Opin Neurol 2013;26:59-66.

2. Pranzatelli MR, Tate ED, McGee NR, MacArthur CA. Evaluation of responsiveness to reduced-dose rituximab in corticotropin/intravenous immunoglobulin/rituximab combination immunotherapy for opsoclonus-myoclonus syndrome. Ped Neurol 2018;85:71-75.

3. Kinsbourne M. Myoclonic encephalopathy of infants. J Neurol Neurosurg Psychiatry 1962;25:271.

4. Fitzpatrick AS, Gray OM, McConville J, McDonnell GV. Opsoclonus-myoclonus syndrome associated with benign ovarian teratoma. Neurology 2008;70:1292-1293.

5. Lou E, Hensley ML, Lassman AB, Aghajanian C. Paraneoplastic opsoclonusmyoclonus syndrome secondary to immature ovarian teratoma. Gynecol Oncol 2010; 117:382-384

6. Kawachi I, Saji E, Toyoshima Y, Dalmau J, Nishizawa M. Treatment responsive opsoclonus-ataxia associated with ovarian teratoma. J Neurol Neurosurg Psychiatry 2010;81:581-582.

7. Kanno K, Kin S, Hirose M, Suzuki S, Watanabe T, Fujimori K. Opsoclonus-ataxia syndrome associated with mature teratoma. J Obs Gyn Resear 2015;41:1149-1153.

8. Urriola NX, Helou J, Maamary J, et al. NMDA receptor antibody in teratoma-related opsoclonus-myoclonus syndrome. J Clin Neurosci 2018;58:203-204.

9. Armangue TM, Titulaer L, Sabater J, et al. A novel treatment-responsive encephalitis with frequent opsoclonus and teratoma. Ann Neurol 2014;75:435-441.

10. Pranzatelli MR, Tate ED, McGee NR, et al. Key role of CXCL13/CXCR5 axis for cerebrospinal fluid B cell recruitment in pediatric OMS. J Neuroimmunol 2012;243: 81- 88 .

\section{AAN Online Learning}

Browse a variety of online CME, self-assessment, and other learning activities to suit your wide-ranging interests and learning styles. Visit AAN.com/Learn. 


\section{Neurology}

Clinical Reasoning: A 16-year-old girl with ataxia, oscillopsia, and behavioral changes Andrew Silverman, Chindhuri Selvadurai, John Picard, et al.

Neurology 2020;94;713-717 Published Online before print March 31, 2020

DOI 10.1212/WNL.0000000000009297

This information is current as of March 31, 2020

Updated Information \& Services

References

Subspecialty Collections

Permissions \& Licensing

Reprints including high resolution figures, can be found at: http://n.neurology.org/content/94/16/713.full

This article cites 10 articles, 3 of which you can access for free at: http://n.neurology.org/content/94/16/713.full\#ref-list-1

This article, along with others on similar topics, appears in the following collection(s):

Adolescence

http://n.neurology.org/cgi/collection/adolescence

All Neuro-ophthalmology

http://n.neurology.org/cgi/collection/all_neuroophthalmology

Clinical neurology examination

http://n.neurology.org/cgi/collection/clinical_neurology_examination

Paraneoplastic syndrome

http://n.neurology.org/cgi/collection/paraneoplastic_syndrome

Information about reproducing this article in parts (figures,tables) or in its entirety can be found online at:

http://www.neurology.org/about/about_the_journal\#permissions

Information about ordering reprints can be found online:

http://n.neurology.org/subscribers/advertise

Neurology ${ }^{\circledR}$ is the official journal of the American Academy of Neurology. Published continuously since 1951, it is now a weekly with 48 issues per year. Copyright () 2020 American Academy of Neurology. All rights reserved. Print ISSN: 0028-3878. Online ISSN: 1526-632X.

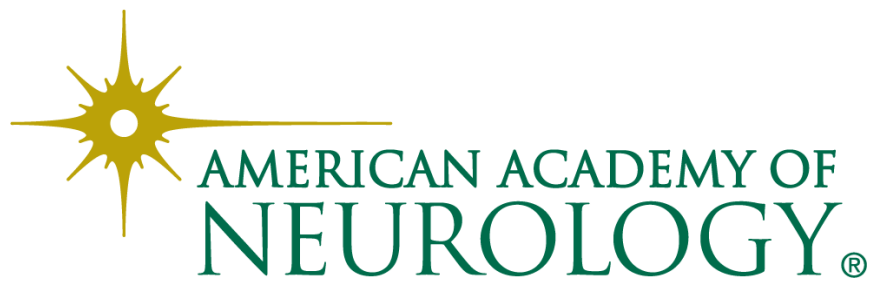

